\title{
BIOSORPTION OF CADMIUM AND LEAD USING MICROALGAE SPIRULINA SP. ISOLATED FROM KOYA CITY (IRAQ)
}

\author{
ABDULKAREEM, P. M. ${ }^{1 *}-$ ANWER, S. S. ${ }^{2}$ \\ ${ }^{1}$ Department of Biology, Health and Sciences Faculty, Koya University, Erbil, Iraq \\ ${ }^{2}$ Department of Clinical Biochemistry, College of Health Sciences, Hawler Medical University, \\ Erbil, Iraq \\ (phone: +964-750-494-3730) \\ *Corresponding author \\ e-mail: parween.mohsin@koyauniversity.org; phone: +964-750-441-2402 \\ (Received 25 ${ }^{\text {th }}$ Aug 2019; accepted $8^{\text {th }}$ Jan 2020)
}

\begin{abstract}
The alternative to the traditional method for heavy metal uptake is biosorption. The potential of Spirulina sp. for biosorption of waste effluent was examined. In this study, morphology and molecular features of microalgae Spirulina $s p$. isolated from Koya city were identified on. The rate of biosorption of cadmium $\left(\mathrm{Cd}^{+2}\right)$ and lead $\left(\mathrm{Pb}^{+2}\right)$ were studied by using a spectrophotometer. The optimum uptake for both metals $\mathrm{Cd}^{+2}$ and $\mathrm{Pb}^{+2}$ showed at low metal concentration of $100 \mathrm{mgl}^{-1} 88.8 \%$ and $93.6 \%$, respectively. Spirulina sp. showed the ability to remove metals at all $\mathrm{pH}$ values $38.1 \%$ and $85.8 \%$ for $\mathrm{Cd}^{+2}$ and $34.6 \%$ and $88.4 \%$ for the $\mathrm{Pb}^{+2}$ with maximum uptake at $30{ }^{\circ} \mathrm{C} 85.7 \%$ for $\mathrm{Cd}$ and $\mathrm{Pb}$ optimum uptake was $88.4 \%$. Optimum removal showed at agitation rate $150 \mathrm{rpm} 87.1)$ in $\mathrm{Cd}^{+2}$, and $\mathrm{Pb}^{+2}$ optimum adsorption at 150 rpm was $89.9 \%$. Both metals showed optimum adsorption at $1.5 \mathrm{~g} \mathrm{l}^{-1}$ of algal biomass, $\mathrm{Cd}^{+2}$ removed $86.7 \%$, and $\mathrm{Pb}^{+2} 89.2 \%$. $\mathrm{Pb}^{+2}$ showed the best performance for metal biosorption.
\end{abstract}

Keywords: metal uptake, algal biomass, temperature, agitation rate, $\mathrm{pH}$

\section{Introduction}

Microalgae include those chlorophyll-bearing organisms that are thalloid (Vashishta et al., 2002). Nearly $75 \%$ of algal species are microalgae that contribute $30-40 \%$ of oxygen to the atmosphere (Ponuswamy et al., 2013). They are the primary producers who switch water and carbon dioxide into carbohydrates and oxygen in the presence of the sun (Chisti, 2008). Microalgae biomass is often measured with a concentration of chlorophyll and can provide a useful index of potential production.

Cadmium $\left(\mathrm{Cd}^{+2}\right)$ is a chemical element that involves different machinery to induce its harmful effect on many biological activities in humans, animals, and various other organisms. In humans, the adverse effect of $\mathrm{Cd}^{+2}$ is not only limited to the kidney and bone, but it includes nearly every organ and tissue where it accumulates, which argues the need for public health measures aimed at reducing exposure. There are many ways in which this heavy metal can be suppressed in its activities, forming the prospect for reduced metal toxicity involving $\mathrm{Cd}^{+2}$ (Hogan, 2010; Sharma et al., 2015).

Lead $\left(\mathrm{Pb}^{+2}\right)$ is number two on the "Top 20 List" of toxic and hazardous substances of the ATSDR. $\mathrm{Pb}^{+2}$ accounts for the majority of pediatric heavy metal poisoning (Roberts, 1999). $\mathrm{Pb}^{+2}$ occurs in many forms worldwide in natural sources and is one of the most commonly and uniformly distributed trace metals (Jackson et al., 2005). $\mathrm{Pb}^{+2}$ creates several adverse effects in both males and females on the reproductive system. Common impacts shown in males involve decreased libido, unusual spermatogenesis (decreased motility and number), chromosomal harm, infertility, abnormal prostatic function, and 
serum testosterone alterations. Women, on the other hand are more prone to infertility, miscarriage, premature membrane rupture, pre-eclampsia, pregnancy hypertension, and premature delivery (Flora et al., 2011). Also, during gestation, the direct influence of $\mathrm{Pb}^{+2}$ on the developmental stages of the fetus was registered (Saleh et al., 2009; Flora et al., 2012). Hasson (2018) measured concentrations of some heavy metals in various imported and locally produced vegetable crops in Baghdad city, including root crops and the daily intake of four main heavy metals $(\mathrm{Cd}, \mathrm{Cu}, \mathrm{Zn}$, and $\mathrm{Pb})$ had been estimated, which revealed a high consumption of $\mathrm{Cd}^{+2}$ (310 and $372 \mu \mathrm{g}$ per day) for imported and local vegetables that affect human health. Because of multiple anthropogenic activities, heavy metals are released into the fairway. Their therapy is of particular significance since heavy metals are non-biodegradable and cause environmental damage due to their poisoning to many crops, livestock, and microorganisms in the aquatic environment (Sadettin and Donmez, 2007; Kaplan, 2013; Salih et al., 2017). Traditional methods for the removal of dissolved heavy metal ions involve chemical precipitation, electrochemical treatment, chemical oxidation and reduction, ion exchange, filtration and evaporative recovery (Aksu et al., 2002). Biosorption of heavy metals by microalgae is generally a biphasic process involving adsorption by materials associated with extracellular cells, such as polysaccharides and cell wall components (Roy et al., 1993; Das et al., 2008).

\section{Materials and methods}

\section{Sampling and cultivation}

Microalgae sample was isolated along Taq-Taq river in Koya city during MaySeptember 2018, Water samples were taken from a depth between 10 and $50 \mathrm{~cm}$ from the bottom (Prasad et al., 2013) and plated Blue-green 11 medium (BG11) as described by Allen (1968) and Oswaled (1988). The cultures were incubated at $\mathrm{pH} 7.8$ and $28{ }^{\circ} \mathrm{C}$ under constant light $800 \mathrm{Lx}$. Two weeks later, following the growth of colonies on the agar media, the colonies were removed with pasture micropipettes and gently blown into the liquid medium, then incubated at $28^{\circ} \mathrm{C}, 800 \mathrm{Lx}$, and $\mathrm{pH} 7.8$.

\section{Morphological and molecular identification of algae}

After a 15-days single colony removed and examined under a light microscope for identification purposes based on their morphology as described by Prescott (1963), Desikachary (1968), Rippka (1988) and Holt et al. (1994). Further identification was performed by polymerase chain reaction (PCR) to confirm algal genera.

\section{Extraction of DNA}

Genomic DNA extraction was performed using a commercial extraction kit (Thermofisher, USA) according to the manufacture's instruction. DNA samples were then checked for their quantity and quality using Bio-photometer (Eppendorf, German).

\section{PCR amplification and DNA sequencing}

The targeted region of 16S rRNA of algae amplified by PCR using universal primers, forward primer A8F (5- AGAGTTTGATCCTGGCTCAG-3), and the reverse primer A1492R (5- TACGGCTACCTTGTTACGACTT- 3). Primers were previously used by 
Ponnuswamy et al. (2008). A total of $50 \mu \mathrm{l}$ volume of the reaction mixture was prepared, which contained 40-55 ng DNA, $100 \mathrm{mM}$ of each primer, $0.05 \mathrm{U} / \mu \mathrm{l} \mathrm{Taq}$ DNA polymerase, $4 \mathrm{mM} \mathrm{MgCl} 2$, and $0.4 \mathrm{mM}$ of each dNTP.

ABI 3130XL genetic analyzer (USA) was employed to find the order of the nucleotides of $16 \mathrm{~S}$ rRNA for the algae sample. The PCR products were cut from the agarose gel and utilized as a base of DNA template for sequence-specific PCR amplification and sent for nucleotide sequencing analysis to the private medical genetic laboratory in Intergene Genetic Center, Ankara, Turkey.

\section{Preparation of biomass}

Spirulina sp. biomass initially dried from moisture on an aluminium tray, kept in the oven at $80{ }^{\circ} \mathrm{C}$ for $24 \mathrm{~h}$, after cooling, this material was subjected to sieve analysis.

\section{Chemicals}

Cadmium nitrate tetrahydrate $\left(\mathrm{Cd}\left(\mathrm{NO}_{3}\right)_{2} \bullet 4 \mathrm{H}_{2} \mathrm{O}\right)$ and lead nitrate $\left(\mathrm{Pb}\left(\mathrm{NO}_{3}\right)_{2}\right)$ were used to prepare $1000 \mathrm{mg} \mathrm{l}^{-1}$ inventory metal ion solutions that were diluted to produce metal ion alternatives for adsorption. Before the microorganisms were mixed, the $\mathrm{pH}$ value of each metal solution was adapted with $1 \mathrm{~mol} \mathrm{l}^{-1} \mathrm{NaOH}$ to the appropriate value (Fan et al., 2008).

\section{Batch experiments}

Batch experiments were performed at different initial metal concentrations 100$500 \mathrm{mgl}^{-1}$, pH 6.5-8.5, temperature $20-40{ }^{\circ} \mathrm{C}$, agitation speed from zero-200 rpm, and biosorbent dosage 0.3-1.5 $\mathrm{gl}^{-1}$ according to Aksu (2005). The rate of biosorption was read using spectrophotometer at $540 \mathrm{~nm}$ for $\mathrm{Cd}^{+2}$ and $530 \mathrm{~nm}$ for the $\mathrm{Pb}^{+2}$. Metal containing medium was used as blank (control medium contained both metals and solution without biosorbent to observe any reaction of the solution with metals). Each experiment was carried out in triplicate. The yield of biosorption was determined ( $E q$. 1) by the formula below (Blanco et al., 1999; Aksu, 2005):

$$
\text { Biosorption } \%=(C o)-(C) \cdot 100 / C o
$$

$\mathrm{C}_{\mathrm{o}}$ - Initial metal concentration, $\mathrm{C}$ - Final metal concentration.

\section{Statistical analysis}

The test results were statistically analyzed with a one-way variance analysis (ANOVA) followed by a Tukey post hoc test $(\mathrm{P} \leq 0.5)$ to assess significant differences between the experimental classes.

\section{Results}

\section{Morphological and molecular identification of algal strain}

After observation under the microscope at different magnifications and according to the guide of taxonomic, in the isolated and purified samples trichomes width without akinetic and heterocyst, cell length, pointed calyptras, type of coil and helix shape (Fig. 
1) were observed and identified as Spirulina according to Ciferri (1983), Rippka (1988), Tomasseli (1997) and Prasal et al. (2013).

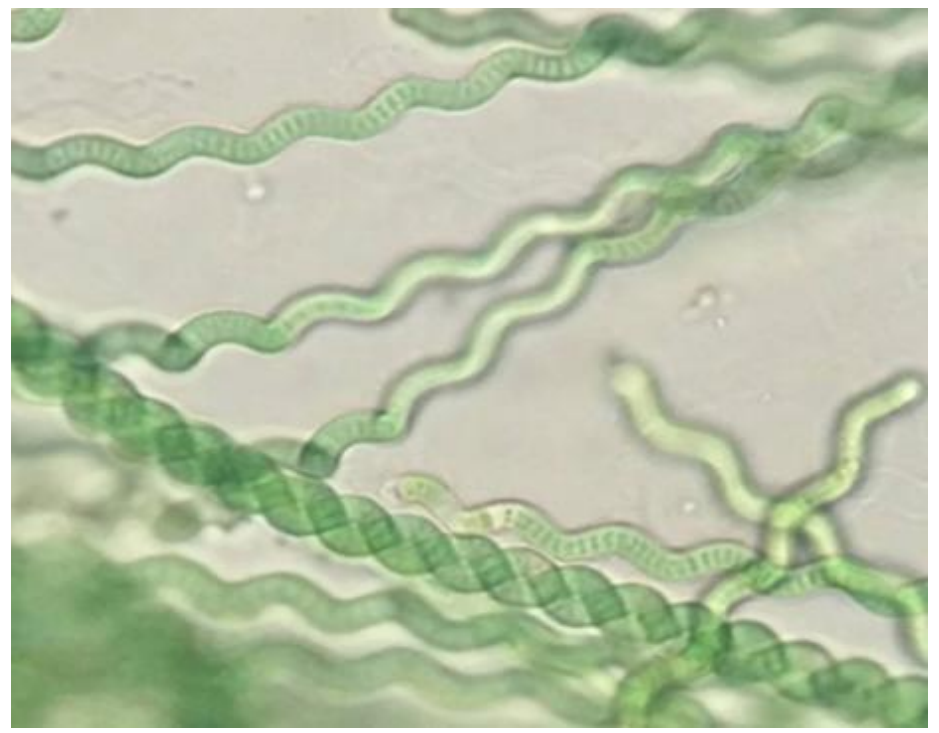

Figure 1. Microscopic observation of Spirulina sp.

By molecular examination, the sequence from 16S rDNA of algae specimen was made of 1200-1400 bp (amplified fragment was $1468 \mathrm{bp}$, also after testing some nonnucleotides were removed, linked to the character of the sequencing assessment) and then placed to BLAST compared to other stored algae sequence genus from the Gene Bank database. The primary sequence analysis using a universal primer of the observed specimen disclosed that algae from Koya city belong to the Spirulina $s p$. genus. Its rDNA conforms to the same rDNA sequence fragment symbol required at the Gene Bank in the National Center for Biotechnology Information (NCBI), pairwise analysis of the algae specimen is shown in Figure 2.

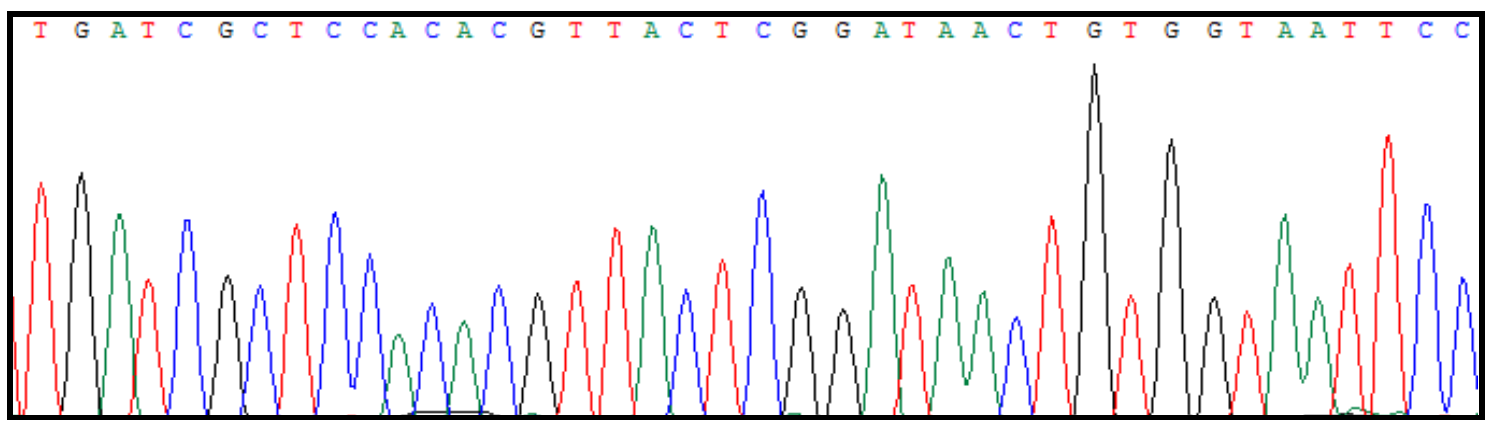

Figure 2. The partial sequencing result of $16 S$ rDNA of Spirulina sp.

\section{Effect of $\mathrm{Cd}$ and Pb concentrations on biosorption}

Figures 3 and 4 showed the effect of initial metal ion concentration $\left(\mathrm{Cd}^{+2}\right.$ and $\left.\mathrm{Pb}^{+2}\right)$ ranging from (100-500 $\left.\mathrm{mg} \mathrm{l}^{-1}\right)$. Optimum removal showed during $15 \mathrm{~h}$, and the rapid removal showed at hour 3; by increasing metal concentration, the biosorption process decreased. In the case of $\mathrm{Cd}^{+2}$, the optimum adsorption $(88.8 \%)$ was recorded at a 
concentration of $100 \mathrm{mg} \mathrm{l}^{-1}$, while high removal of $\mathrm{Pb}^{+2}$ was $(93.6 \%)$ at the same concentration. Increasing concentration of both metal ions led to a decline in adsorption, indicating saturation of all the binding sites on the algal surface. The result showed that there were no significant differences between heavy metal concentration with $\mathrm{Cd}^{+2}(p-$ value $=0.0936)$ and $\mathrm{Pb}^{+2}(p$-value $=0.0981)$.

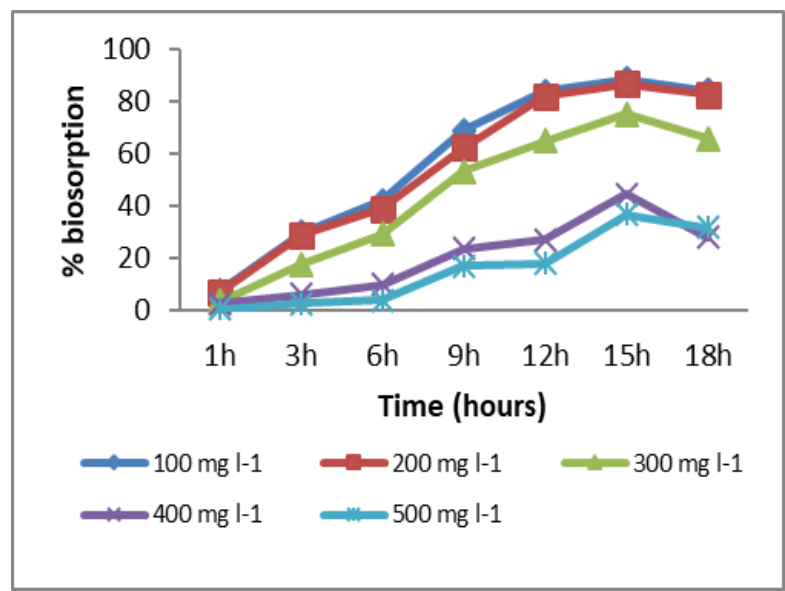

Figure 3. Effect of metal $\mathrm{Cd}^{+2}$ concentration on biosorption process $\left(\mathrm{pH} 7,35^{\circ} \mathrm{C}, 100 \mathrm{rpm}\right)$

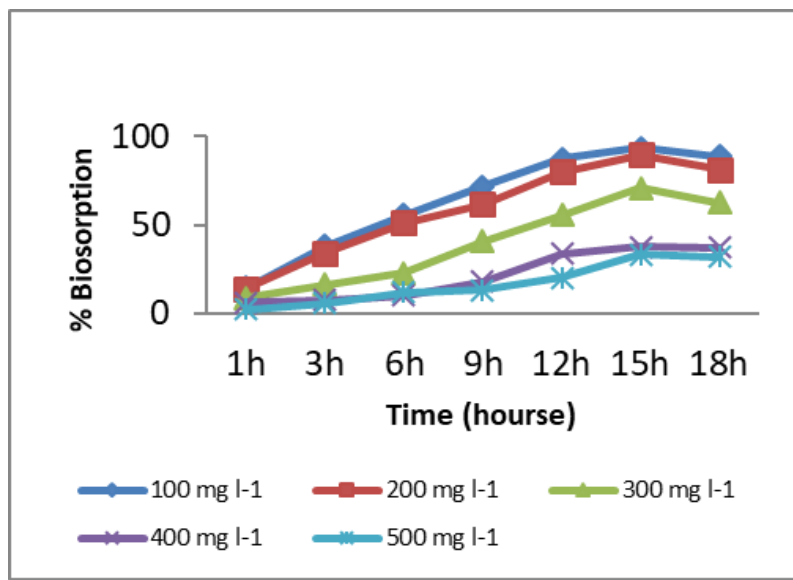

Figure 4. Effect of metal $\mathrm{Pb}^{+2}$ concentration on biosorption process $\left(\mathrm{pH} 7,35^{\circ} \mathrm{C}, 100 \mathrm{rpm}\right.$ )

\section{Effect of $\mathrm{pH}$ on biosorption of $\mathrm{Cd}$ and $\mathrm{Pb}$ by Spirulina sp.}

The $\mathrm{pH}$ is an important factor in biosorption processes. To find an appropriate $\mathrm{pH}$ for Spirulina sp. efficient heavy metal biosorption, studies were conducted at five distinct original $\mathrm{pH}$ values $(6.5,7,7.5,8,8.5)$, Spirulina $s p$. showed ability to remove metals at all $\mathrm{pH}$ values $38.1 \%$ and $85.8 \%$ for $\mathrm{Cd}^{+2}$ and $34.6 \%$ and $88.4 \%$ for the $\mathrm{Pb}^{+2}$. The Statistical analysis showed significant differences among $\mathrm{pH}$ and adsorption percentage of both $\mathrm{Cd}^{+2}$ and $\mathrm{Pb}^{+2}$ ions. A significant correlation had been recorded among $\mathrm{pH}$ degree change with both $\mathrm{Cd}^{+2}(p$-value $=0.0039)$ and $\mathrm{Pb}^{+2}(p$-value $=0.0065)$, which means with increasing $\mathrm{pH}$, the adsorption percent increased, and the peak of adsorption percent was reached to 85.8 for $\mathrm{Cd}^{+2}$ and $88.4 \mathrm{for}^{\mathrm{Pb}^{+2}}$ ion. The optimum removal showed at $\mathrm{pH} 8\left(\mathrm{Cd}^{+2} 85.8 \%\right.$ and $\left.\mathrm{Pb}^{+2} 88.4 \%\right)$ as shown in Table 1 . 
Table 1. Effect of $\mathrm{pH}$ on biosorption of $\mathrm{Cd}^{+2}$ and $\mathrm{Pb}^{+2}$ by Spirulina sp. $\left.200 \mathrm{mg} \mathrm{l}^{-1}\right), 35^{\circ} \mathrm{C}$, $100 \mathrm{rpm}$

\begin{tabular}{|c|c|c|c|c|c|c|}
\hline \multirow{2}{*}{ pH } & \multicolumn{3}{|c|}{ Spirulina sp. $\left(\mathrm{Cd}^{+2}\right)$} & \multicolumn{3}{|c|}{ Spirulina sp. $\left(\mathbf{P b}^{+2)}\right.$} \\
\hline & $\mathrm{C}_{0}\left(\mathrm{mg} \mathrm{l}^{-1}\right)$ & $\mathrm{CC}_{0}\left(\mathrm{mg} \mathrm{l}^{-1}\right)$ & \%Adsorption & $\mathrm{C}_{0}\left(\mathrm{mg} \mathrm{l}^{-1}\right)$ & $\mathrm{CC}_{0}\left(\mathrm{mg} \mathrm{l}^{-1}\right)$ & \%Adsorption \\
\hline 6.5 & 167.9 & 63.9 & 38.1 & 162.7 & 56.3 & 34.6 \\
\hline 7 & 178.6 & 122.2 & 68.4 & 172.7 & 108.7 & 62.9 \\
\hline 7.5 & 188.6 & 157.2 & 83.3 & 178.7 & 147.4 & 82.5 \\
\hline 8 & 214.3 & 183.9 & 85.8 & 192 & 169.7 & 88.4 \\
\hline 8.5 & 202.1 & 169.6 & 83.9 & 183.3 & 156.6 & 85.5 \\
\hline
\end{tabular}

\section{Effect of temperature on biosorption of $\mathrm{Cd}^{+2}$ and $\mathrm{Pb} \mathrm{b}^{+2}$ by Spirulina sp.}

To find an appropriate temperature for Spirulina sp.'s on efficient heavy metal adsorption, studies were conducted at five distinct temperature values $(20,25,30,35$, and $40{ }^{\circ} \mathrm{C}$ ) as shown in Figures 5 and 6 . Rapid removal showed in first hour at $20^{\circ} \mathrm{C}$. Optimum removal of $\mathrm{Cd}^{+2}$ showed at a temperature of $30{ }^{\circ} \mathrm{C}(85.7 \%)$, and for $\mathrm{Pb}^{+2}$, optimum removal was $(88.4 \%)$ at the same temperature. The effect of temperature showed significant differences among temperature and adsorption percentage of both $\mathrm{Cd}^{+2}$ and $\mathrm{Pb}^{+2}$ ions. Significant differences had been stated related to temperature change in both $\mathrm{Cd}^{+2}(p$-value $=0.025)$ and $\mathrm{Pb}^{+2}(p$-value $=0.0248)$ biosorption.

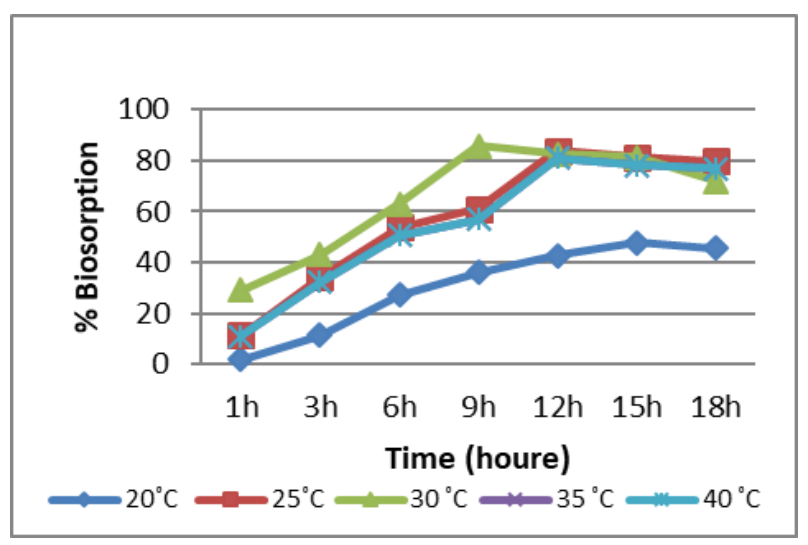

Figure 5. Effect of temperature on $\mathrm{Cd}^{+2}$ adsorption $\mathrm{C}_{0^{-}} 200 \mathrm{mg} \mathrm{l}^{-1}, \mathrm{pH} 8,100 \mathrm{rpm}$

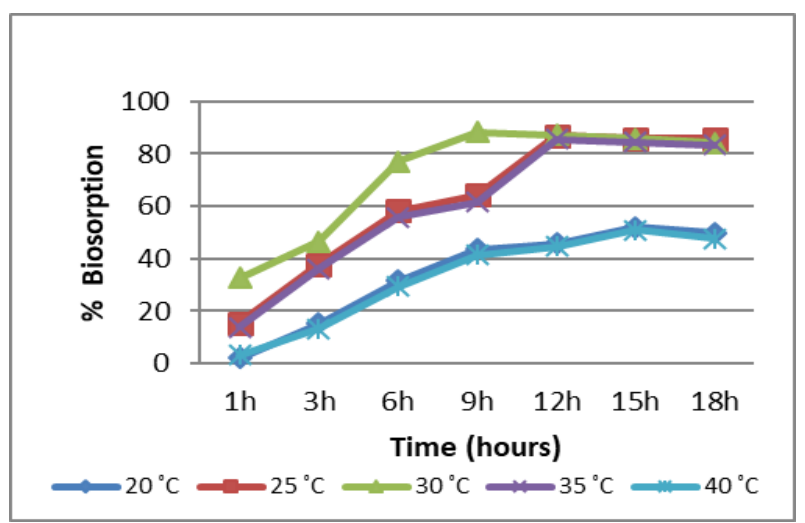

Figure 6. Effect of temperature on $\mathrm{Pb}^{+2}$ adsorption by Spirulina sp. $\mathrm{C}_{0^{-}} 200 \mathrm{mg} \mathrm{l^{-1 }}$, $\mathrm{pH} \mathrm{8,} 100$ rpm 


\section{Effect of agitation rate (rpm) on biosorption of $\mathrm{Cd}^{+2}$ and $\mathrm{Pb}^{+2}$ by Spirulina sp.}

The effect of agitation rate on $\mathrm{Cd}^{+2}$ and $\mathrm{Pb}^{+2}$ adsorption by Spirulina $s p$. is shown in Table 2. At equilibrium, metal uptake increases with an increase of agitation rate - rpm (unshaken to $150 \mathrm{rpm}$ ), and the optimum removal showed at rpm $150(87.1 \%)$ in $\mathrm{Cd}^{+2}$ and $\mathrm{Pb}^{+2}$ showed optimum adsorption at $150 \mathrm{rpm}(89.9 \%)$. The adsorption process decreased with $200 \mathrm{rpm}$. The $p$-value of $\mathrm{Cd}^{+2}(p$-value $=0.469)$ and $\mathrm{Pb}^{+2}(p$-value $=0.5031)$ that showed no significant correlation between rpm, in spite of increasing rpm, the adsorption percent of $\mathrm{Cd}^{+2}$ and $\mathrm{Pb}^{+2}$ ions were not changed significantly.

Table 2. Effect of agitation rate on biosorption of $\mathrm{Cd}^{+2}$ and $\mathrm{Pb}^{+2}$ by Spirulina sp. $\left(200 \mathrm{mg} \mathrm{l}^{-1}\right.$ initial metal concentration $\left.\left(\mathrm{C}_{0}\right), \mathrm{pH} 8,30^{\circ} \mathrm{C}\right)$

\begin{tabular}{|c|c|c|c|c|c|c|}
\hline \multirow{2}{*}{ Agitation rate } & \multicolumn{3}{|c|}{ Spirulina sp. $\left(\mathbf{C d}^{+2}\right)$} & \multicolumn{3}{|c|}{ Spirulina sp. $\left(\mathbf{P b}^{+2}\right)$} \\
\hline & $\mathrm{Co}_{0}\left(\mathrm{mg} \mathrm{l}^{-1}\right)$ & $\mathrm{CC}_{0}\left(\mathrm{mgl}^{-1}\right)$ & \%Adsorption & $\mathrm{C}_{0}\left(\mathrm{mg} \mathrm{l}^{-1}\right)$ & $\mathrm{CC}_{0}\left(\mathrm{mg} \mathrm{I}^{-1}\right)$ & \%Adsorption \\
\hline $\begin{array}{c}\text { Unshaken } \\
\text { (non-agitated) }\end{array}$ & 122.1 & 26.1 & 21.3 & 186 & 59.0 & 31.7 \\
\hline $50 \mathrm{rpm}$ & 127.9 & 76.5 & 59.8 & 197.3 & 102.6 & 52.0 \\
\hline $100 \mathrm{rpm}$ & 141.4 & 119.6 & 84.6 & 208 & 179 & 86.1 \\
\hline $150 \mathrm{rpm}$ & 146.4 & 124.6 & 87.1 & 212 & 185 & 89.9 \\
\hline $200 \mathrm{rpm}$ & 132.1 & 106.0 & 80.3 & 204 & 174.3 & 85.5 \\
\hline
\end{tabular}

\section{Effect of algal biomass on biosorption of $\mathrm{Cd}^{+2}$ and $\mathrm{Pb}^{+2}$ by Spirulina sp.}

The effect of biomass on $\mathrm{Cd}^{+2}$ and $\mathrm{Pb}^{+2}$ ion removal is indicated in Figures 7 and 8 . At equilibrium, metal uptake increases with an increase in biomass from 0.3 to $1.5 \mathrm{~g} \mathrm{l}^{-1}$. Optimum removal showed during $6 \mathrm{~h}$ in a biomass of $1.5 \mathrm{~g} \mathrm{l}^{-1}$, rapid removal showed at $1 \mathrm{~h}$ in a biomass of $0.3 \mathrm{~g} \mathrm{ml}^{-1}$. Both metals showed optimum adsorption at $1.5 \mathrm{~g} \mathrm{l}^{-1}$ of algal biosorbent $86.7 \%$, of $\mathrm{Cd}^{+2}$ and $89.2 \%$ of $\mathrm{Pb}^{+2}$ were removed.

The result showed significant differences among algal biomass and adsorption percent of both $\mathrm{Cd}^{+2}$ and $\mathrm{Pb}^{+2}$ ions. The $p$-value for both $\mathrm{Cd}^{+2}(p$-value $=0.0095)$ and $\mathrm{Pb}^{+2}$ ( $p$-value $\left.=0.0036\right)$, means with increasing of algal biomass, the adsorption percent increase and the peak of adsorption percent was reached to 86.7 for $\mathrm{Cd}^{+2}$ and 89.2 for $\mathrm{Pb}^{+2}$ ion.

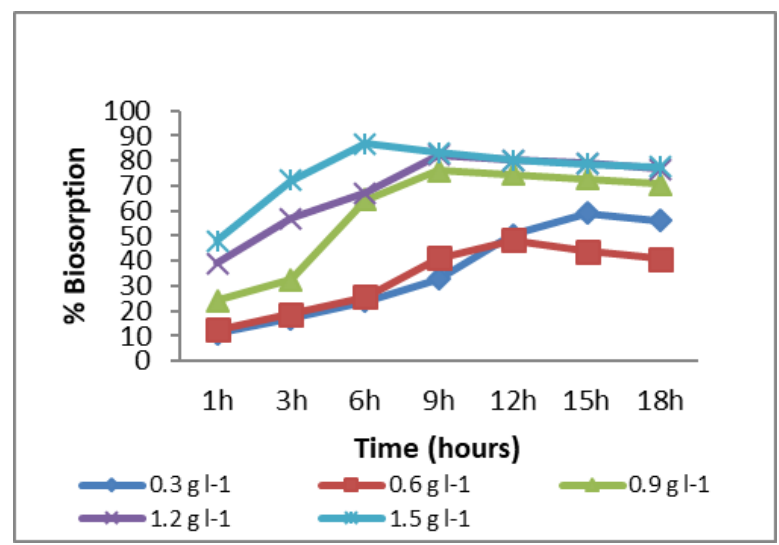

Figure 7. Effect of biosorbent dosage on $\mathrm{Cd}^{+2}$ adsorption (200 $\mathrm{mg} \mathrm{l}^{-1}$ initial metal concentration, $\mathrm{pH} 8,30^{\circ} \mathrm{C}, 150 \mathrm{rpm}$ ) 


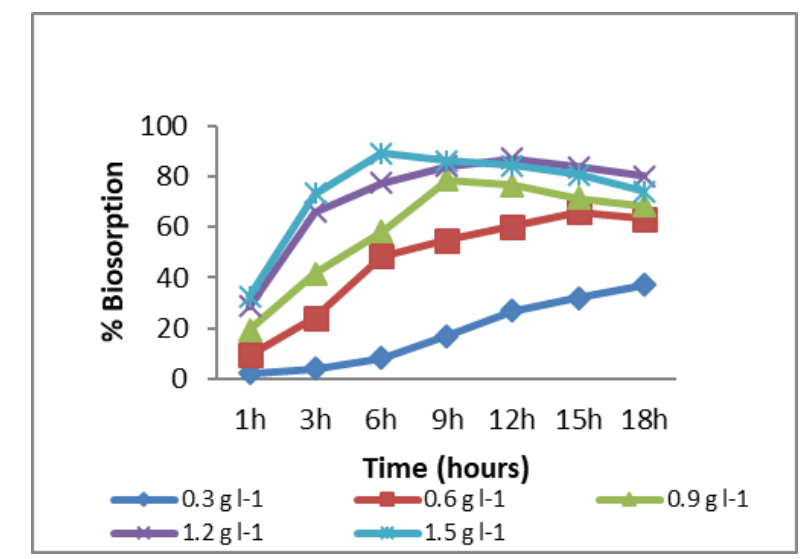

Figure 8. Effect of biosorbent dosage on $\mathrm{Pb}^{+2}$ adsorption (200 $\mathrm{mg} \mathrm{l}^{-1}$ initial metal concentration, $\mathrm{pH} 8,30^{\circ} \mathrm{C}, 150 \mathrm{rpm}$ )

\section{Scanning electron microscopy (SEM) analysis}

The biosorbent morphology, which is cell/filamentous algae-binding- $\mathrm{Pb}^{+2}$ and $\mathrm{Cd}^{+2}$, was examined using SEM with 200x magnification to demonstrate the porous places of cell/filamentous algae as seen in (Fig. $9 a, b, c)$ illustrate the efficient binding with $\mathrm{Cd}^{+2}$ and $\mathrm{Pb}^{+2}$, respectively. However, in composites with a greater content of $\mathrm{Cd}^{+2}$ and $\mathrm{Pb}^{+2}$, the particles are often abnormal in form and circular in the preparing of irregular surface, this distinctive shift in the analyzed SEM pictures highlights the existence of $\mathrm{Cd}^{+2}$.

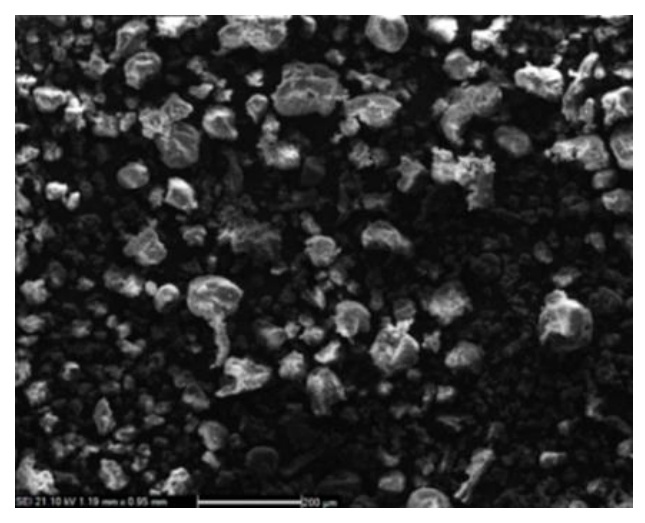

a

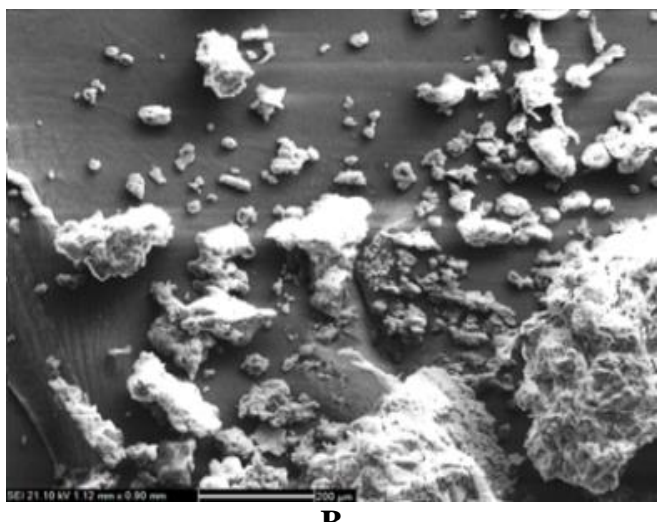

$\mathbf{B}$

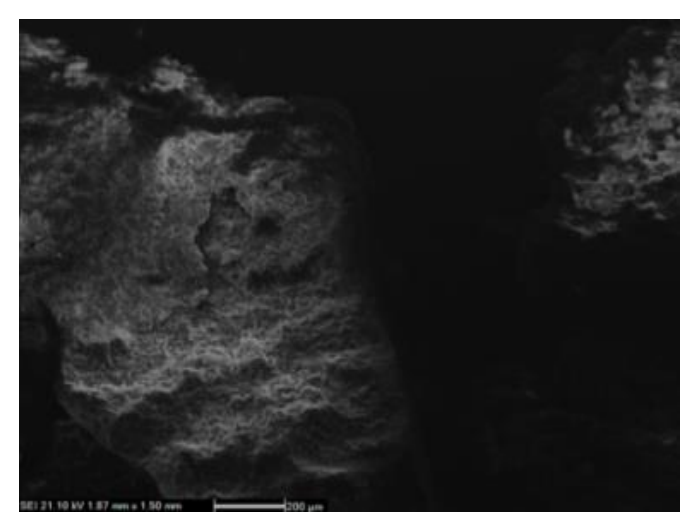

C

Figure 9. SEM image Spirulina (a) before adsorption, (c) and (c) binding $\mathrm{Cd}^{+2}$ and $\mathrm{Pb}^{+2}$ and on the cell/filamentous algae surface 


\section{Discussion}

Isolated and purified microalgae strain observed under microscope and culture showed filamentous spiral-shaped microalgae that were identified as Spirulina sp. and the strain was confirmed by using molecular identification. The same characteristics showed by isolated Spirulina from (Koya city). In many cases, the selection of efficient organism is known to be essential tools in the successful treatment of wastewater effluents rich in toxic compounds such as $\mathrm{Cd}$ (II) and $\mathrm{Pb}$ (II) in textile industry effluents. Microalgae were proposed as perfect candidates for the wastewater treatment system. In the present research, Spirulina strain was used as biomass for $\mathrm{Cd}^{+2}$ and $\mathrm{Pb}^{+2}$ adsorption process under various initial metal concentrations, $\mathrm{pH}$, biosorbent dosage, temperature, and agitation velocity. In the experiments, it was showed that there are different factors affecting the biosorption of heavy metals by Spirulina sp. The present results were in agreement with Gupta and Rastogi (2008), König-Péter et al. (2015). AlHomaidan et al. (2015) and Palaniswamy and Veluchamy (2017). As shown in the results, $\mathrm{Pb}^{+2}$ biosorption was more prominent than $\mathrm{Cd}^{+2}$ biosorption. Similar results were obtained by Domínguez-Bocanegra et al. (2013), who reported that $\mathrm{Pb}^{+2}$ biosorption was more prominent than $\mathrm{Cd}^{+2}$ and nickel. By increasing the original metal concentration, the proportion of biosorption of metal ions reduced (Figs. 3 and 4) same result was obtained by Abdel-Aty et al. (2013).

The fast adsorption of the metals shows that the sorption method may be ionic where the acidic (anionic) dye molecules bind to the multiple strongly loaded organic functional groups present on the biomass surface (Gulnaz et al., 2004).

$\mathrm{pH}$ is one of the most significant parameters affecting original adsorption frequency and ability; the optimum $\mathrm{pH}$ was 8 (Table 1). This phenomenon is due to the nature of the chemical interaction of each heavy metal with algal cell walls. Hydrogen ion also functions as a bridging ligand between the cyanobacterial cell wall and the heavy metal molecules, and the results were in agreement with Abdel-Aty et al. (2013) who confirmed that the biosorption of $\mathrm{Cd}$ (II) and $\mathrm{Pb}$ (II) was increased with increasing the $\mathrm{pH}$ value and disagreed with König-Péter et al. (2015) who stated that the biosorption process was successful at $\mathrm{pH} 5-6$ for $\mathrm{Pb}$ (II) and $\mathrm{pH}$ 4-6 for $\mathrm{Cd}(\mathrm{II})$ adsorption. Metals biosorption on Spirulina sp. has been researched at various temperatures of $20-40{ }^{\circ} \mathrm{C}$, and the optimum temperature for adsorption of metals showed at $30{ }^{\circ} \mathrm{C}$ and the lowest adsorption at $20^{\circ} \mathrm{C}$ (Figs. 5 and 6). However, temperature variation in comparisons had an important impact on the removal of $\mathrm{Cd}^{+2}$ and $\mathrm{Pb}^{+2}$ of Spirulina $s p$. The results of this investigation were in agreement with Donmez et al. (1999), Dhargalkar (2004) and König-Péter et al. (2015). To determine the impact of agitation velocity on metal adsorption, a series of studies at distinct agitation degrees (unagitated - $200 \mathrm{rpm}$ ) were conducted and shown in Table 2 indicating that the degree of agitation positively affected the sorption process rise in agitation rate biosorption of metals improved optimum adsorption at $150 \mathrm{rpm}$ with agitation levels greater than $200 \mathrm{rpm}$. This relates to the weakening interaction between the sorbent locations and the metal ion described by the Van-der Waals interaction Anwer and Abdullah (2017) when they study the effect of agitation rate on direct Blue nine adsorption using baker's yeast.

Figures 7 and 8 showed the effect of biosorbent dosage to remove heavy metal, Optimum removal showed in biomass 1.5 at $6 \mathrm{~h}$, fast removal showed in biomass 0.3 at $1 \mathrm{~h}$. By increasing biosorbent dosage adsorption of biomass increased due to increase in the region and the accessibility of more biosorption locations (Mane et al., 2007). After 
biosorption process ended the algal biomass accumulated and used for further study which was desorption experiments.

However, in composites with a higher content of $\mathrm{Cd}^{+2}$ and $\mathrm{Pb}^{+2}$, the particles are mainly abnormal in form and circular in the preparation of a rougher surface, this distinctive shift in the analyses SEM pictures highlights the existence of $\mathrm{Cd}^{+2}$ and $\mathrm{Pb}^{+2}$ in the cell/filamentous algae surface this result is agreed with Salih et al. (2017).

\section{Conclusion}

Biosorption of heavy metals $\left(\mathrm{Cd}^{+2}\right.$ and $\left.\mathrm{Pb}^{+2}\right)$ increased by increasing biosorbent (Spirulina sp.). This study shows that isolated Spirulina sp. deserves attention as biosorbent, which can be utilized in the treatment of wastewater effluents containing heavy metals before the treatment, and the technique can be modified further to make it applicable on a large scale to clean up heavy metal contamination using dried biomass of Spirulina sp. In most of the studies that done previously by researchers spirulina cells were purchased in the dried form while in our research we isolated spirulina from different site of Koya city which was not conducted before, and cultured Spirulina sp. by using different parameters to obtain high rate of biomass in lab.

Acknowledgements. The authors would like to thank Salahaddin University-Erbil, College of Education and Koya University, for their support.

\section{REFERENCES}

[1] Abdel-Aty, A. M., Ammar, N. S., Ghafar, H. H. A., Ali, R. K. (2013): Biosorption of cadmium and lead from aqueous solution by fresh water alga Anabaena sphaerica biomass. - Journal of Advanced Research 4(4): 367-374.

[2] Aksu, Z. (2005): Application of biosorption for the removal of organic pollutants: a review. - Process Biochemistry 40(3-4): 997-1026.

[3] Aksu, Z., Gönen, F., Demircan, Z. (2002): Biosorption of chromium (VI) ions by Mowital ${ }^{\circledR}$ B30H resin immobilized activated sludge in a packed bed: comparison with granular activated carbon. - Process Biochemistry 38(2): 175-186.

[4] Al-Homaidan, A. A., Alabdullatif, J. A., Al-Hazzani, A. A., Al-Ghanayem, A. A., Alabbad, A. F. (2015): Adsorptive removal of cadmium ions by Spirulina platensis dry biomass. - Saudi Journal of Biological Sciences 22(6): 795-800.

[5] Allen, M. M., Stanier, R. Y. (1968): Growth and division of some unicellular blue-green algae. - Microbiology 51(2): 199-202.

[6] Anwer, S. S., Abdullah, B. A. (2017): Biosorption of Direct Blue9 using baker's yeast (Saccharomyces cerevisiae). - ZANCO Journal of Pure and Applied Sciences 28(6): 170175.

[7] Blanco, A., Sanz, B., Llama, M. J., Serra, J. L. (1999): Biosorption of heavy metals to immobilised Phormidium laminosum biomass. - Journal of Biotechnology 69(2-3): 227240.

[8] Chisti, Y. (2008): Biodiesel from microalgae beats bioethanol. - Trends in Biotechnology 26(3): 126-131.

[9] Ciferri, O. (1983): Spirulina, the edible micro-organism. - Microbiological Reviews 47: 551-578.

[10] Das, N., Vimala, R., Karthika, P. (2008): Biosorption of heavy metals - an overview. Indian Journal Biotechnology 7: 159-169. 
[11] Desikachary, V. (1968): Cyanophyta, Chrococcales. - Academic Press, New York and London.

[12] Dhargalkar, V. K. (2004): Effect of different temperature regimes on the chlorophyll a concentration in four species of Antarctic macroalgae. - Seaweed Res. Util. 26: 237-243.

[13] Domínguez-Bocanegra, A., Torres-Muñoz, J., Aguilar López, R. (2013): Biosorption of cadmium (ii), lead (ii) and nickel (II) by Spirulina maxima. - International Journal of Sciences 2(2): 45-55.

[14] Dönmez, G. Ç., Elmaci, A., Obali, O., Öztürk, A., Çakmakçi, L. (1999): Isolation and abundance of unicellular Cyanobacteria from mosquito development sites. - Turkish Journal of Biology 23(4): 451-456.

[15] Fan, T., Liu, Y., Feng, B., Zeng, G., Yang, C., Zhou, M., Wang, X. (2008): Biosorption of cadmium (II), zinc (II) and lead (II) by Penicillium simplicissimum: isotherms, kinetics and thermodynamics. - Journal of Hazardous Materials 160(2-3): 655-661.

[16] Flora, G., Gupta, D., Tiwari, A. (2012): Toxicity of lead: a review with recent updates. Interdisciplinary Toxicology 5(2): 47-58.

[17] Flora, S., Pachauri, V., Saxena, G. (2011): Arsenic, Cadmium and Lead. Reproductive and Developmental Toxicology. - Academic Press, New York, 415-438.

[18] Gulnaz, O., Kaya, A., Matyar, F., Arikan, B. (2004): Sorption of basic dyes from aqueous solution by activated sludge. - Journal of Hazardous Materials 108(3): 183-188.

[19] Gupta, V. K., Rastogi, A. (2008): Biosorption of lead from aqueous solutions by green algae Spirogyra species: kinetics and equilibrium studies. - Journal of Hazardous Materials 152(1): 407-414.

[20] Hasson, H. A. (2018): Heavy metals contamination for some imported and local vegetables. - Iraqi Journal of Agricultural Sciences 49(5): 794-802.

[21] Hogan, C. M. (2010): Encyclopedia of Earth. - National Council for Science and the Environment, Washington, DC.

[22] Holt, G., Rieg, R., Smeath, A., Staley, T., Williams, T. (1994): Berge's Manual of Determinative Bacteriology. 9th Ed. - LWW, Philadelphia, PA.

[23] Jackson, R. N., Baird, D., Els, S. (2005): The effect of the heavy metals lead ( $\mathrm{Pb} \mathrm{2+)}$ and zinc (Zn 2+) on. - Water SA 31(1): 107-116.

[24] Kaplan, D. (2013): Absorption and Adsorption of Heavy Metals by Microalgae. - In: Richmond, A., Hu, Q. (eds.) Handbook of Microalgal Culture: Applied Phycology and Biotechnology. Wiley, Hoboken, NJ, pp. 602-611.

[25] König-Péter, A., Kilár, F., Felinger, A., Pernyeszi, T. (2015): Biosorption characteristics of Spirulina and Chlorella cells for the accumulation of heavy metals. - Journal of the Serbian Chemical Society 80(3): 407-419.

[26] Mane, V. S., Mall, I. D., Srivastava, V. C. (2007): Use of bagasse fly ash as an adsorbent for the removal of brilliant green dye from aqueous solution. - Dyes and Pigments 73(3): 269-278.

[27] Oswaled, W. (1988): Microalgae and Waste Water Treatment - In: Borowitizka, M. A., Borowitizka, L. J. (eds.) Microalgae Biotechnology. Cambridge University Press, Cambridge, pp. 305-328.

[28] Palaniswamy, R., Veluchamy, C. (2017): Biosorption of heavy metals by Spirulina platensis from electroplating industrial effluent. - Environ Sci Ind J 13(4): 139.

[29] Ponnuswamy, I., Soundararajan Madhavan, D., Shabudeen, S., Shoba, U. S. (2008): Isolation and identification of green microalgae for carbon sequestration and waste water treatment by using PCR studies. - International Journal of Engineering Science and Innovative Technology 2(5): 263-268.

[30] Ponnuswamy, I., Madhavan, S., Shabudeen, S. (2013): Isolation and characterization of green microalgae for carbon sequestration, waste water treatment and bio-fuel production. - International Journal of Bio-Science and Bio-Technology 5(2): 17-25.

[31] Prasad, R. N., Sanghamitra, K., Antonia, G. M., Juan, G. V., Benjamin, R. G., Luis, I. M. J., Guillermo, V. V. (2013): Isolation, identification and germplasm preservation of 
different native Spirulina species from Western Mexico. - American Journal of Plant Sciences 4: 65-71.

[32] Prescott, W. (1963): Algae of the Western Great Lakes Area. - Michigan State University, East Lansing, pp. 443-451.

[33] Rippka, R. (1988): Recognition and identification of cyanobacteria. - Methods in Enzymology 167: 28-67.

[34] Roberts, R. (1999): Metal Toxicity in Children. - In: Training Manual on Pediatric Environmental Health: Putting It into Practice. Children's Environmental Health Network, Emeryville, CA. http://www.cehn.org/cehn/trainingmanual/pdf/manualfull.pdf.

[35] Roy, D., Greenlaw, P. N., Shane, B. S. (1993): Adsorption of heavy metals by green algae and ground rice hulls. - Journal of Environmental Science and Health Part A 28(1): 37-50.

[36] Sadettin, S., Dönmez, G. (2007): Simultaneous bioaccumulation of reactive dye and chromium (VI) by using thermophil Phormidium sp. - Enzyme and Microbial Technology 41(1-2): 175-180.

[37] Saleh, H. A., El-Aziz, G. A., El-Fark, M. M., El-Gohary, M. (2009): Effect of maternal lead exposure on craniofacial ossification in rat fetuses and the role of antioxidant therapy. - Anatomia, Histologia, Embryologia 38(5): 392-399.

[38] Salih, S. J., Anwer, S. S., Faraj, R. H. (2017): a biosorption of mercury from wastewater using isolated Aspergillus Sp. modified 1, 10-phenanthroline: Hill Isotherm Model. Science Journal of University of Zakho 5(4): 288-295.

[39] Sharma, H., Rawal, N., Mathew, B. B. (2015): The characteristics, toxicity and effects of cadmium. - International Journal of Nanotechnology and Nanoscience 3: 1-9.

[40] Tomaselli, L. (1997): Morphology, Ultrastructure and Taxonomy of Arthrospira (Spirulina) Maxima and Arthrospira (Spirulina) Platensis. - In: Vonshak, A. (ed.) Spirulina Platensis (Arthrospira): Physiology, Cell-Biology and Biotechnology. Taylor \& Francis, London, pp. 1-16.

[41] Vashishta, B. R., Snha, A. K., Singh, V. P. (2002): Botany for Degree Students - Algae. Introduction to Algae. - S. Chand Publishing, New Delhi, pp. 1-30. 